\title{
AN APPROACH TO CULINARY TOURISM DEVELOPMENT IN TURKEY
}

\begin{abstract}
Alev Dündar ${ }^{1}$
Abstract: Cuisine and foodways play a vital role as part of the living culture of each destination, attracting masses of cultural travelers. Mediterranean countries like Italy, Greece and Turkey as well as several Asian countries like Thailand and Korea are considered prominent culinary tourism destinations.Culinary tourism is considered to be a new niche that is a precious tool to contribute to economic, community, social and intercultural development. Culinary tourism helps to build and sustain regional and local identities, may enhance the local agricultural resources as well as food and beverage supplies. At the same time it provides opportunities to create new tourism products and experiences. Many studies also have shown that culinary has a great impact on travelers' decisions when choosing their vacation destination. Therefore, unique cuisines not only build popular travel destinations but also improve the culinary cultural image of a country, which makes the culinary culture a major attraction within the travel destination.Sports, health, cultural, religious and culinary tourism are also the new emerging tourism products in Turkey. As a synthesis of east and west, the culture of Turkey is reflected very much in its culinary tradition. Turkey's traditional cuisine has had a double identity, by which the tastes of east and the traditions of west create a pleasant mix and experience. Turkish cuisine picks up everything which is worth taking from different cultures and cuisines and adds to the local styles of cuisine that makes the experience unique for visitors. The traditional flavours and ingredients have been playing an important role in the Turkish culinary heritage for centuries. In this paper the relationship of the culinary heritage with the tourism development in terms of sustainability is discussed. Suggestions are made for possible implications for marketing, promotion and development of culinary tourism in Turkey.
\end{abstract}

Key words: Culinary Heritage, Culinary Tourism, Destination Development, Turkey.

\section{INTRODUCTION}

According to Timothy and Nyaupane (2009) one of the five prevalent forms of cultural tourism, which are important constituents of the cultural tourism product globally, is "Culinary Heritage". Culinary tourism has been defined as an experience part of cultural tourism, including consumption of food and drink that represents the local, regional or national cuisine, culture, heritage and tradition. It draws an image of the heritage, the inhabitants and the landscape of a geographic area. Culinary tourism is considered to be a new niche that is a precious tool to contribute to economic, community, social and intercultural development. Furthermore, cooking is observed as a certain kind of medium in terms of tourism (Scarpato, 2002).

The term Culinary Tourism or Food Tourism was developed by Lucy Long in 1998 (Wolf, 2004). "Whether you go to food or food comes to you, the nature of the encounter is what defines a food experience as culinary tourism" (Long, 2003). It is apparent that there is a relationship between food, beverage, travel and attractions at any tourist destination. The International Culinary Tourism Association defines culinary tourism as, "the pursuit of unique and memorable eating and drinking experiences." Culinary tourism occurs when visitors seek to experience cuisine and culture together. Examples of culinary tourism include wine tourism in California, cheese sampling in Wisconsin, maple syrup tasting in

\footnotetext{
${ }^{1}$ Assistant Professor Dr., Department of Gastronomy and Culinary Arts, Faculty of Tourism, Anadolu University, Eskişehir, Turkey.
} 
Vermont, and Cajun food experiences in Louisiana. A diverse range of businesses including farms, restaurants, gourmet or specialty food stores, cooking schools, tour operators, breweries, wineries, historical attractions and many other related businesses across the country have capitalized on their regions' culturally unique cuisines to attract visitors. Culinary tourism is a new trend that unites the food, beverage and travel industries. While culinary tourism can be looked at as a tool for economic and community development, it's a new concept that celebrates unique and memorable culinary experiences as an integral part of a tourist's experience(www.culinarytourism.org.).

Culinary tourism helps to build and sustain regional and local identities, may enhance the local agricultural resources as well as food and beverage supplies. At the same time it provides opportunities to create new tourism products and experiences. It can become a way of sharing memorable stories and telling them with pride to the visitors. As Robert J. Harrington (2005) states "classic wine and food examples illustrate many of the similarities and contrasting characteristics in components, texture and flavours. An understanding of these concepts can be valuable when defining gastronomic tourism strategies and local restaurant concepts".

Cuisine and foodways play a vital role as part of the living culture of each destination, attracting masses of cultural travelers. Mediterranean countries like Italy, Greece and Turkey as well as several Asian countries like Thailand and Korea are considered prominent culinary tourism destinations. Many researchers revealed tourists spend almost $40 \%$ of their budget on food when travelling (Boyne, Williams, \& Hall, 2002). Culinary tourism can thrive in relation of agriculture, which consists of farm holidays, farmers' market and fruit orchards and highlights the exploration and delight of prepared food and drink.Gastronomy in tourism is more than just dining out while being on holiday; it is an experience focusing on local culture and traditions including the 5 senses (Wolf, 2004). Gastronomy has a significant connection to the edible world, whether it is about travelling to a destination or consuming a gastronomic product at a certain place, the neighbourhood and the experience is what classifies the term culinary tourism. Where food is the centre of motivation as in culinary art and gastronomy, there must be a certain place for cooking schools, wineries, restaurants and festivals (Long, 2003).

Recent economical, social, technological and political developments in the world, ledto changes in consumptionpatterns in tourism sector.Murphy, Pritchard and Brock (2000) argue that visitors consume the products of a destination; therefore, the products must be something that the visitors want and need. Therefore for the sustainability of the tourism industry,new products for the special interest travelers has to be developed. Until recently tourism has only seen as a sea-sun-sand fun or cultural activity, the contribution of food to tourism has been largely ignored in spite of its apparent importance and potential (Tellfer \& Wall, 1996; Handszuh, 2000). Culinary tourism can also generally refer to travel in which the goal is exploring and enjoying local delicacies and gaining memorable culinary experiences(Wolf, 2004). Furthermore, culinary, gastronomic and cuisine oriented tourists also tend to be perceived as high yield (Hall \& Sharples, 2008).

As gastronomy and regional food add value to a destination, also they contribute to the sustainable competitiveness of a destination (Crouch \& Ritchie). The importance of food and drink in tourism development plays a significant role in many countries, destinations, tourism organisations, tour operators, travel agents and stakeholders (UNWTO, 2012). According to the International Culinary Tourism Association, culinary tourism is growing exponentially every year. With the steady increase in interest of food channels, travel shows featuring local and regional cuisine, food documentaries and online culinary travel 
shows, more consumers are traveling to various destinations just to enjoy a new food and wine experience.Culinary heritage holds big potential to enhance sustainability in tourism industry.

\section{CULINARY HERITAGE IN TOURISM}

Levi Strauss (1966) states that, as there no societies in the world without a language, also no society without a culinary tradition.From purpose point of view the people travel throughout the world for business or pleasure. In both cases you will have a lot of opportunities to taste the local food and beverage. It is regarded as part of the change and it is considered to be a general habit that you can't wait to see and discover something new in life. Food and drink have recently become an important aspect of recreational travel. At present the culinary tourism tends to become an own industry within an industry, and a lot of special organizations appear to provide resources for such programs and develop best practices at the same time. This is a segmented business, a very special niche market of the tourism industry, which is growing rapidly and the outlook for growth seems to be bright in the future as well, however, it is usually combined with other cultural tours, cycling, walking, visiting museums, adventure, medical tours etc. Consequently, this is a segment that appeals to a broad range of consumers.

The consumers pursue to be aware of the benefits of economic and healthy local products and they deliberately seek to sample and enjoy local dishes, foods and drinks. This strong desire has led to the emergence of local food and drink festivals, which constitute a good instance where the decision to travel is taken solely on the grounds of the gastronomic experiences. And now these events are becoming more prevalent in Europe. The variety of these supplies reflects the differences and similarities in the traditions of the various regions. These attractions typically combine a wide range of different programs at the destination, like visiting farmers' markets, gastronomic museums, confectionery shops, geographic sight-seeing components, tasting at wineries, breweries, dining and/or fruitpricking at farms, participating in pig slaughter and on the other side the tourists seem to appreciate them (Bujdosó, Kerekesné Mayer, \& Ujvári, 2012).

Culinary tourism has the potential to bring local people and visitors closer together. The rapid development of modern technology, which shapes and dominates every aspect of human life, has positive impact on the culinary tourism, too. Tourists tend to plan their trips using online as well as print media, which provides wide options and choices, resulting in severe competition in the industry. In addition we have the media popularising eating trends, recipes, cooking blogs, and we have TV shows like "how to cook", "kitchen chefs" etc. All these serials obviously create the interest of people in experiencing another culture through its cuisine in the existing and emerging culinary tourism destinations and result in appearance of conscious culinary tourist. In response, private entrepreneurs are widely using technology to innovate and differentiate their business to withstand the massive competition in the industry. Web coupons, iPad wine-lists or restaurant interactive multimedia order terminal, which helps create innovative dishes, are good examples of technology adoption in food industry (Yeoman, 2008).

Any person who travels to a destination for any reason consumes the local food. Researchers state that gastronomy is a part of tourism experience and in some cases can be the basic motivational factor (Horng at.all. 2012). There is a certain correlation betwen the tourists interested in wine and food and tourists interested in museums, shopping, festivals, shows and recreational events (Kesici, 2012). The basic motivational factors of 
gastronomy tourism are; to taste a special local delight, watch the production process of special foods, visit the restaurants, festivals, food producers, observe the different production tecniques of food or taste food prepared by a famous chef (Yüncü, 2009). The travelers enjoy indegenous food, particularly items of localor ethnic nature (Wagner, 2001). In the modern globalized world, people are interested about local, regional and national cuisine. Local food is a fundamental component of a destination's attributes, adding to the range of attractions and the overall tourist's experience. Food is an attraction, is a product component, is an exprience, and is a cultural phenomenon (Tikkanen, 2007). Many studies also have shown that culinary has a great impact on travelers' decisions when choosing their vacation destination. Therefore, unique cuisines not only build popular travel destinations but also improve the culinary cultural image of a country, which makes the culinary culture a major attraction within the travel destination. It shows that there is a symbolic relationship between food and the tourism industry.

Culinary tourism has an important potential to enhance tourist attractions and helps the marketing and the sustainability of tourism. Tourists travel for pleasure and want to experience and enjoy the host culture's food. The increasing interest in local cuisine is a pull factor in the tourism promotion of the destinations. To implement this, local and regional food needs to be researched, studied and applied to modern cuisine in balance. Local ingredients, and flavors should be used. In many countries, regarding food tourism is that local food in the form of regional cuisine is rarely present as an important resource in publicity material and promotional messages prepared for mainstream tourism (Handszuh, 2000).By promoting local cuisines and the cultures that created them, regional tourism markets can bolster their revenues while preserving local customs and heritage, catering to the increasing demands and desires of culinary tourists (Blakey, 2011). Destinations nowdays understand that food and cuisines represent a core element their invisible heritages, demonstrating their national cultural characteristics and local features- which can even be developed into an international brand (Horng, J.S. \& Tsai, C.T., 2010).

In addition, a new lifestyle in the $21^{\text {st }}$ century has become widely recognised and supported. It is about the health conscious eating. Nowadays, most people aim to improve their body confidence in the long run, desire a well-shaped figure and tend to be more serious about making changes to their lifestyle and prefer to have a healthy, proper metabolism and digestion (Cousens, 2000). Other factors like the demographical changes in Europe, which means the rapid and continuous growth in number of elderly people, and the general economic development, which results in the increasing disposable income of people, all these factors will boost the demand for culinary services and different food tastes (Shenoy, 2005).

\section{CULINARY HERITAGE IN TURKEY}

Mass tourism has been the leading engine of tourism industry in Turkey for many years.Until 1990's almost all of the marketing efforts has been oriented towards the beaches of Eagean and Mediterranean's sea, sand and sun tourism. In recent years alternative tourism activities has attracted the attention of travelers as new tourism products. Sports, health, cultural, religious and culinary tourism are the new emerging tourism products.

As a synthesis of east and west, the culture of Turkey is reflected very much in its culinary tradition. A rich and diverse blend of cultural influences accumulated over the years, the cuisine of Turkey offers travelers a sumptuous spread of the traditional Turkish dishes. All 
different regions of the country have their own culinary heritage. It's very important to study, search and explore the possible opportunities to promote culinary heritage like Roman, Byzantine, Ottoman cuisines and culinary tourism for sustainability.

Turkish cuisine is one of the living oldest and richest cuisines in the world. If we study the development process of Turkish cuisine, it goes back to Central Asian cuisine which blended with Anatolian cuisine. As the Ottoman Empire extended its lands, the richness of its cuisine also increased with new lands and cultures. The meat and fermented milk products from Central Asia, spices from South Asia and Middle East, Mediterranean fruits and vegetables were combined and formed rich Turkish culinary culture. The range of ingredients used is similarly vast, with recipes incorporating every kind of meat, fish, vegetable, and fruit,besides a myriad of spices. Spices are also important products of culinary tourism. Their use are closely related to cultural identities at local, regional and national levels. Spices are key to making a dish a national symbol, as for example with paprika and goulash for Hungary. Cuisines that cross cultures, such as Mediterranean diet, rely on spices (Jolliffe, 1. 2014).

Dishes based on seafood, beef,lamb, goat, chicken, goose; casseroles combining meat and vegetables: cold vegetable dishes cooked in olive oil; stuffedvegetables, salads, fruit compotes and drinks; milk puddings are some examples of what Turkish cuisine has to offer.Halva has several flavors, is mixed with walnuts, peanuts and pistachios, and also comes in different variaties. Turkish delight, or lokum, comes in dozens of variaties and color combinations. Rimmington and Yüksel (1998) found that the majority of travelers revisited Turkey for its cuisine, and food was the fourth factor that would contribute to travelers overall satisfaction (Hu \& Ritchie, 1993). According to the TURSAB (Turkish Travel Agencies Association) Gastronomy Tourism Report 2015, 88.2\% of tourists declare that "food is very important in destination preference". A destinations culinary heritage is a touristic product and its importance rises in recent years.

Turkey's traditional cuisine has had adouble identity, by which the tastes of east and the traditions of west create a pleasant mix and experience. Turkish cuisine picks up everything which is worth taking from different cultures and cuisines and adds to the local styles of cuisine that makes the experience unique for visitors. The traditional flavours and ingredients have been playing an important role in the Turkish culinary heritage for centuries. Turkish cuisine uses basic, fresh ingredients in a simple way. The most common ingredients are probably: herbs and spices, onion, garlic, green peppers, tomatoes, paprika, potatoes, and wide range of meats and last but not least the famous ground red pepper. Paprika powders can differ in granulation, colour, and aroma and most significantly in taste from sweet to tremendously hot. The natural abundance of fruits and vegetables make eating in Turkey a delight.

In 2008 the Ankara Chamber of Commerce (ATO) and Ankara Patent Bureau have conducted research on Turkey's various cuisines and prepared a taste map covering hundreds of meals peculiar to 81 provinces of the country. The results of the research indicates that Turkey is a "delicious country" with its rich cuisine composed of more than 2.205 local meals and drinks. While the province of Gaziantep has the richest cuisine comprising 291 different types of meals, sweets and drinks altogether, the province of Elazı $\breve{g}$ is home of a rich cuisine with a total of 154 types of meals, desserts and drinks. Another province, Ankara, the capital of Turkey, also has rich cuisine with 93 different types of food.

Among the traditional desserts all around Turkey, Bolu's "kedi batmaz" (cat will never sink), Şanlıurfa's "ş1llı" (gaudily dressed woman), Kocaeli's "otur Fatma" (sit down 
Fatma), and Tokat's "bacaklı çorba" (soup with legs) are just a few examples of sweets with striking and absurd names. Central Anatolia is Turkey's richest region in terms of cuisine thanks to 455 different types of food and drinks. Çiğ köfte (raw meatballs) and künefe (sweet cheese pastry) are two types of food that is not peculiar to a single cuisine but to cuisines in a number or provinces (http://www. Hurriyetdailynews.com/default.aspx?pageid=438\& n=turkish-press-scanner-2015-10-8).

On the South part of Turkey, Antakya (Antiocheia) is now a candidate UNESCO "World City of Gastronomy". Until now only three cities have been granted this title: Popayan in Columbia, Chengdu in China and Ostersund in Sweden. The cuisine of the city with its multi-religious, multi-cultural background and dishes is defined by a mixture of Anatolian, French, Arabic and Nomadic cuisines. There are more than 600 dishes in Antakya where three major religions and different cultures have coexisted for centruies. There are more than 150 foods only for breakfast. The Antakya cuisine, defined mostly with Mediterranean foods like, oil, butter, graines and legumes, mainly include bulgur (cracked wheat), meat, spices, pomegranate syrup, pepper paste and salty yoghurt. Vegetable dishes are cooked with lots of tomato paste and pepper. Naturally grown healing herbs like kömeç, mint, parsley and thyme are used in dishes (TÜRSAB, 2015).

Although it's very important to have goods registered by geographical indication for national and international promotions, Turkey only have 124 geographically indicated nourishments. Traditional Ceremonial Keskek (2011), Mesir Paste (2012), Turkish Coffee and Tradition (2013) are in the UNESCO's Intangible Cultural Heritage List. Central Anatolia Region 455, South Eastern Anatolia Region 398, Black Sea Region 397, Mediterraneanand Marmara Regions 184, and Aegean Region have 162 different types of food and beverages. There are so many diverse cuisines in Turkey which have totally different features from region to region have a big potential for culinary tourism. It only needs positioning and effective marketing to be worldwide brands in international tourism market (Kalpaklığlu, 2015).

\section{CONCLUSION AND RECOMMENDATIONS}

Cultural tourism is one of the largest and fastest-growing global tourism markets. Culture is increasingly being used in order to promote destinations and improve their competitiveness and attractiveness. Many destinations are now actively developing their tangible and intangible cultural resources as a means of developing comparative opportunities in an increasingly competitive tourism industry. According to the World Tourism Organization, cultural tourism is growing globally at a rate of $15 \%$ per year, and at the same time $37 \%$ of all trips nowadays contain a cultural component. Culinary tourism, as part of the living culture of each destination, attracts masses of cultural travelers and provides opportunities to create new tourism products and experiences.

Nowadays, two trends are fighting each other, namely internationalization of cuisines and regionality. Local and traditional events and festivals are getting to be more valued and appreciated. Therefore, people partly want to preserve their culture and taste, the flavours and recipes of good old times, on the other hand they are also willing to try out something totally new and unfamiliar like a guest when they are not at home. Food festivals and events are considered to be large tourist attractions, are powerful tools for sharing culinary experience, cultural and natural resources and developing the rural tourism market. In addition, rural regions can be part of sustainability efforts and initiatives. Rural regions could be defended, preserved, protected from risks of urbanization. They should be 
properly managed in order that they could remain available for the visitors and an economic use of all those living in the territory. The length of stay of travellers at the destination could be extended and accordingly the expenditures. Collaboration between locals and institutions could be maximized for regional advantage. The coordination of public and private institutions to promote culinary tourism should be encouraged. (Millan, G. and et. all. 2014). Meetings between public and private entities should also be promoted to coordinate the actions to be carried out to develop culinary tourism in Turkey.

Development of new visitor attractions related to culinary heritage and products like farmers market, cookery schools and courses, cultural gastronomy tours, wine or olive oil tasting and educational farms are possible alternatives. Travel agents and tour operators that specialize in culinary tourism may offer insider tips and recommendations for creating a custom itinerary based on the traveler's goals and budget. Travelers can choose from selfguided tours, food demonstration events and cooking-lesson packages based on their budget and destination. For example,there is increasing interest in olive oil products, particularly in the health, beauty and leisure sectors. Many rural farms are combining their production activities with tourism hospitality, offering guest accommodation and on-site beauty centres, using their own olive-based cosmetic products and oils (Croce, E. \& Perri, G., 2011).

Regarding the marketing tools one must aware that the internet has become the main channel of collecting travel information and booking recently. Nowadays travelers tend to use it while they look for unique and fun dining venues and share later their experiences as well. Therefore, the culinary service-providers, owners of restaurants and wine-cellars must be familiar with the modern tools in order to evoke interest with the prospective guests, provide the necessary information to them and allow them to make use of online booking and purchase.

Farms could accept guests to experience the farming process and providing meal with the local products directly from the farm. Travelers can have guided tours and meetings with the food producers. They can also learn about the local coffee or tea culture by participating in local people's houses. Activation of local culinary heritage, such as traditional food fairs should be organised. A well-planned culinary tourist product can respond to all the needs and offer excellent opportunities and experiences for the families with children(Croce, E. \& Perri, G., 2011).

For the development of culinary tourism in Turkey, a gastronomy map and tour routes can be developed. Gastronomy routes can contribute the sustainability of tourism in different regions. Round trips for gastronomy tours in the country can be organized like archeological and cultural tours. These tours can be regional or round trips. The tourists can taste and experience different delicacies from different regions. These tours can also be backed with archeological and historical sites, like visiting Ephesus in the morning and joining a workshop with lectures about old Helenistic or Roman cuisine or vegetable dishes of Aegean Region. The fruits, vegetables, herbs, spices of the region can be tasted. Ottoman cuisine can be experienced after visiting Topkapi Palace and other Ottoman relics. Gastronomy tours with special themes can be organized like "Tour of Ottoman Cuisine" or "Tour of Vegetable Dishes" (Kalpaklığlu, 2015).

In general culinary tourism can be regarded as a good way and as a niche market which deserves key attention of the organizers and program developers because it increases tourism generated and municipal tax revenues, maintains employment and creates new jobs, contributes to growth potentials, economic and community developments of the 
regions, diminishes regional economic disparities, induces local people to remain in their region and finally looks for strategic partnerships.

Culinary TV programmes and films could support the culinary promotion of the country. Education through documentation and preservation of the culinary heritage must be the task of the locals and governmental bodies. In order to develop a culinary heritage product, it is necessary to establish consequent services of the tourism industry, planned and systematic marketing support provided not only by local bodies but also by regional and country authorities.

The key success factors in culinary tourism are to continuously stimulate reactions of the 5 senses meaning sight, hearing, taste, smell and touch, to keep a diverse array of product offers appealing to guest, to create memorable experiences and surprises, to have an ongoing interactive communication with the guests in order to find out their future expectations. As Sanches, et al. (2012) mention, culinary heritage provides a business card from anywhere in the world and must be constantly reviewed and maintained by the local community to make it a sustainable heritage.

Culture and tourism are two strongly interrelated notions, since the modern tourist -better educated and cultured, with high demands- attempts to gratify new needs, among which is the acquaintance with new cultures, customs and traditions on places of interest. In parallel, the touristic exploitation of culture through its enhancement and promotion, contributes significantly to the development of each cultural destination. Therefore, in the recent years cultural tourism is one of the largest markets with rapid growth. Within this tourism context, Turkey constitutes one of the classic tourism destinations of the Mediterranean, by combining unique natural diversity and exceptional cultural heritage. In the last years the need to develop alternative forms of tourism, especially sports, health, cultural, religious and culinary tourismbecome apparent, where Turkey has an indisputable advantage.

\section{REFERENCES}

Blakey, C.(2012). Consuming Place: Tourism's Gastronomy Connection. University of Hawai'i at Hilo: Hawai'i Community College HOHONU,Vol (10), pp. 51-54.

Boyne, S., Williams, F.,\&Hall, D. (2002). The Isle of Arran Taste Trail. In A.M. Hjalager\&G.Richards (Eds.), Tourism and Gastronomy. London, England: Routledge, pp.91-114.

Bujdosó, Z., Kerekesné Mayer, Á., \& Ujvári, K. (2012). Gastronomy in Hospitality and Catering. Budapest: Károly Róbert College. pp.5-7.

Cousens, G. (2000). Conscious Eating. Berkeley, California: North Atlantic Books.

Croce, E. \& Perri, G. (2011). Food and Wine Tourism, Cabi Tourism Texts,Cambrige University Press. pp.108-132.

Crouch, G.I., Ritchie, J.R.B. (1999). Tourism, Competitiveness and Social Prosperity. Journal of Business Research, (44), pp.137-152.

Hall, C.M.,Sharples, L. (2008). Food and Wine Festivals Around the World, in the book Mair,M.\&Wagner,D., Culinary Tourism, New York: Springer Verlag. 2012, pp.4-151. 
Handszuh, H. (2000). Local Food in Tourism Policies. Paper Presented at International Conference on Local Food and Tourism. Larnaka, Cyprus.

Horng, J., Horng, S., Tsai C. (2012). Culinary Tourism Strategic Development: An AsiaPacific Perspective. International Journal of Tourism Research,(14), pp.40-55.

Hu, Y., \& Ritchie, J.R.B., (1993). Measuring Destination Attractiveness: A Contextual Approach. Journal of Travel Research, 32(2), pp.25-34.

Jolliffe, 1., (2014). Spices and Tourism. Bristol:Channel View Publications, p.4.

Kalpaklığlu, N.Ü.,(2015). The Role of Gastronomy Tourism in Destination Marketing. Touravel'15, 2. International Tourism and Travel Studies Conference. Point Hotel, Istanbul, 18. June.

Kesici, M, (2012). Kırsal Turizme Olan Talepte Yöresel Yiyecek ve İçecek Kültürünün Rolü.KMU Sosyal ve Ekonomik Araştırmalar Dergisi, 14(23), pp.33-37.

Long, L. M. (2003). Culinary Tourism. Lexington: The University Press of Kentucky. p.12.

Millan, G., Arjona, J. M. \& Amador, L.,(2014).A New Market for Olive Oil: Olive Oil Tourism in the South of Spain. Agricultural Sciences, Vol.(5) No (3), p.183.

Murphy, P., Pritchard, M.P., Brock, S, (2000). The Destination Product and its Impact On Traveller Perceptions. Tourism Management, 21(1), pp. 43-52.

Rimmington, M. \& Yüksel, A., (1998). Tourist Satisfaction and Food Service Experience: Results and Implications of an Empirical Investigation. Anatolia, 9(1), pp.37-57.

Robert J. Harrington, P. (2005). Defining Gastronomic Identity:The Impact of Environment and Culture on Prevailing Components, Texture and Flavours in Wine and Food. Journal of Culinary Science \& Technology4(2/3), p.129.

Sanchez, M.P., Mujica, W.D.C., Luna, A.C.T., (2012). The Cultural Side of the Gourmezt Mexican Tourism in the book: Culinary Tourism, New York: Springer Verlag, p.151.

Scarpato, R. (2002). Gastronomy as a Tourist Product: The Perspective of Gastronomy Studies.(A. M. Hjalager, \& G. Richards, Hrsg.) London and New York: Routledge.pp. 9496.

Shenoy, S. S. (2005). Food Tourism and the Culinary Tourist.Clemson: Clemson University.,pp. 63-68.

Strauss, L., (1966). The Savage Mind, The University of Chicago Press. 
Telfer, D., Wall, G. (1996). Linkages Between Tourism and Food Production. Annals of Tourism Research, 23(3), pp.635-653.

Tikkanen, I. (2007). Maslow's Hierarchy and Food Tourism in Finland: Five Cases. British Food Journal, 109(9), pp. 721-734.

Timothy, J.D., \& Nyaupane, P.G. (2009). Cultural Heritage and Tourism in the Developing World: A regional Perspective. Oxfordshire: Routledge. pp. 8-10.

TURSAB, (2015). No: 361, July, Published by Association of Turkish Travel Agencies, Istanbul, pp:50-53.

TURSAB, (2015). Gastronomy Tourism Report,Istanbul.

UNWTO. (2012). Global Report on Food Tourism. Madrid, Spain: Wourld Tourism Organisation.

Wagner, H., A. (2001). Marrying food and travel. Culinary Tourism. Canada's Food News, Food Service Insight.

Wolf, E. (2004). Culinary Tourism: A Tasty Economic Proposition.Portland: International Culinary Tourism Association,p. 267.

Yeoman, I. (2008). Tomorrow's Tourist: Scenarios \& Trends.New York: Routledge. pp.355-357.

Yüncü, H. R. (2009). Sürdürülebilir Turizm Açısından Gastronomi Turizmi ve Perşembe Yaylası. 10.Aybastı-Kabataş Kurultayı, Eskişehir.

www.culinarytourism.org. 